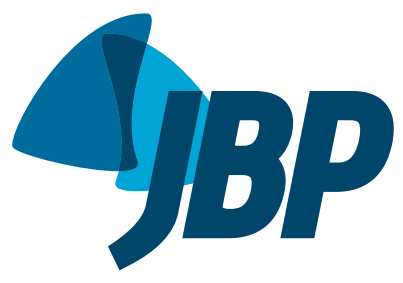

\title{
Effects of a high-intensity pulmonary rehabilitation program on the minute ventilation/carbon dioxide output slope during exercise in a cohort of patients with COPD undergoing lung resection for non- small cell lung cancer
}

\author{
Fabio Perrotta ${ }^{1, a}$, Antonio Cennamo ${ }^{2, b}$, Francesco Saverio Cerqua ${ }^{2, c}$, \\ Francesco Stefanelli3,d, Andrea Bianco ${ }^{2, e}$, Salvatore Musella ${ }^{3, \mathrm{f}}$, Marco Rispoli ${ }^{4, \mathrm{~g}}$, \\ Rosario Salvi ${ }^{5, h}$, llemando Meoli ${ }^{3, i}$
}

1. Dipartimento di Medicina e Scienze della Salute V. Tiberio, Università degli Studi del Molise, Campobasso, Italia.

2. Dipartimento di Scienze Mediche Traslazionali, Ospedale Monaldi. Università della Campania Luigi Vanvitelli Napoli, Italia.

3. Divisione di Pneumologia, Ospedale Monaldi, Napoli, Italia.

4. Dipartimento di Anestesia and Unità di Terapia Intensiva. A.O. dei Colli, Ospedale Monaldi, Napoli, Italia.

5. Dipartimento di Chirurgia Toracica. A.O. dei Colli, Ospedale Monaldi, Napoli, Italia.

a. (iD) http://orcid.org/0000-0002-7223-7037

b. (D) http://orcid.org/0000-0003-3017-0185

c. (iD) http://orcid.org/0000-0001-5522-5889

d. (iD http://orcid.org/0000-0002-1112-1882

e. (iD) http://orcid.org/0000-0002-4692-5901

f. (D) http://orcid.org/0000-0001-6696-2729

g. (D) http://orcid.org/0000-0002-6553-4332

h. (iD) http://orcid.org/0000-0002-2087-7198

i. (D) http://orcid.org/0000-0002-6640-7327

Submitted: 25 April 2018

Accepted: 30 January 2019.

Study carried out at the A.O. dei Colli,

Ospedale Monaldi, Napoli, Italia.

\begin{abstract}
Objective: Preoperative functional evaluation is central to optimizing the identification of patients with non-small cell lung cancer (NSCLC) who are candidates for surgery. The minute ventilation/carbon dioxide output $\left(\mathrm{V}_{\mathrm{E}} / \mathrm{VCO}_{2}\right)$ slope has proven to be a predictor of surgical complications and mortality. Pulmonary rehabilitation programs (PRPs) could influence short-term outcomes in patients with COPD undergoing lung resection. Our objective was to evaluate the effects of a PRP on the $\mathrm{V}_{\mathrm{E}} / \mathrm{VCO}_{2}$ slope in a cohort of patients with COPD undergoing lung resection for NSCLC. Methods: We retrospectively evaluated 25 consecutive patients with COPD participating in a three-week highintensity PRP prior to undergoing lung surgery for NSCLC, between December of 2015 and January of 2017. Patients underwent complete functional assessment, including spirometry, DLCO measurement, and cardiopulmonary exercise testing. Results: There were no significant differences between the mean pre- and post-PRP values (\% of predicted) for $\mathrm{FEV}_{1}(61.5 \pm 22.0 \%$ vs. $62.0 \pm 21.1 \%)$ and DLCO $(67.2 \pm 18.1 \%$ vs. 67.5 $\pm 13.2 \%)$. Conversely, there were significant improvements in the mean peak oxygen uptake (from $14.7 \pm 2.5$ to $18.2 \pm 2.7 \mathrm{~mL} / \mathrm{kg}$ per min; $\mathrm{p}<0.001$ ) and $\mathrm{V}_{\mathrm{E}} / \mathrm{VCO}_{2}$ slope (from $32.0 \pm 2.8$ to $30.1 \pm 4.0 ; p<0.01)$. Conclusions: Our results indicate that a high-intensity PRP can improve ventilatory efficiency in patients with COPD undergoing lung resection for NSCLC. Further comprehensive prospective studies are required to corroborate these preliminary results.

Keywords: Carcinoma, non-small-cell lung; Pulmonary disease, chronic obstructive/ rehabilitation; Carbon dioxide/metabolism; Oxygen consumption/physiology; Risk assessment.
\end{abstract}

\section{INTRODUCTION}

Risk stratification has always been considered crucial in patients with non-small cell lung cancer (NSCLC) undergoing lung resection. The decline in the respiratory function after surgery remains a noteworthy drawback despite the advances in surgical techniques and perioperative care. The current guidelines of the European Respiratory Society and the European Society of Thoracic Surgery ${ }^{(1)}$ strongly suggest the assessment of patients' physical performance by a functional-based algorithm. Peak oxygen uptake $\left(\mathrm{VO}_{\text {2peak }}\right)$ has shown to be the best independent predictor of surgical complication rates ${ }^{(2-7)}$ and, for this reason, cardiopulmonary exercise testing (CPET) is recommended when preoperative $\mathrm{FEV}_{1}$ and/or DLCO are $<80 \%$ of the predicted values. ${ }^{(1)}$ Therefore, preoperative evaluation of respiratory function is one of the most important factors to determine operability, especially in patients with COPD. ${ }^{(1-3,8)}$ Although $\mathrm{VO}_{2 \text { peak }}$ is certainly the most widely used variable, CPET provides various other direct and indirect indicators that change in response to incremental workloads. Consistent data are emerging about the relationship between minute ventilation $\left(\mathrm{V}_{\mathrm{E}}\right)$ and carbon dioxide output $\left(\mathrm{VCO}_{2}\right)$, also called the ventilatory efficiency slope. Patients with lung disease have increased ventilatory requirements for a given level of exercise. ${ }^{(9)}$ In two independent studies that involved patients undergoing lung resections, a higher $\mathrm{V}_{\mathrm{E}} / \mathrm{VCO}_{2}$ slope showed to be a predictor of surgical complications and increased mortality. ${ }^{(3,8)}$ A few studies reported the impact of preoperative pulmonary rehabilitation programs (PRPs) on exertional parameters in cohorts of NSCLC patients undergoing radical surgery. ${ }^{(10-12)}$ Therefore, the 
aim of the present study was to evaluate the effects of a preoperative high-intensity PRP on the $\mathrm{V}_{\mathrm{E}} / \mathrm{VCO}_{2}$ slope in a cohort of patients with COPD undergoing lung resection for NSCLC.

\section{METHODS}

\section{Patients}

We retrospectively evaluated the electronic medical records of 32 consecutive COPD patients attending a preoperative high-intensity PRP prior to undergoing lung surgery for NSCLC, between December of 2015 and January of 2017. Inclusion criteria were having been previously diagnosed with clinical stage I-IIIa NSCLC; being deemed fit for surgery according to the European Respiratory Society/European Society of Thoracic Surgery guidelines ${ }^{(1)}$; being $<80$ years of age; having a body mass index of $18-34 \mathrm{~kg} / \mathrm{m}^{2}$; and presenting with a postbronchodilator fixed $\mathrm{FEV}_{1} / \mathrm{FVC}$ ratio $<0.70$. Exclusion criteria were contraindications to surgery based on baseline CPET; cardiovascular or musculoskeletal disorders limiting training; use of oxygen therapy or noninvasive ventilation for chronic lung failure; cognitive impairment or psychiatric disorders; and pregnancy. The PRP was offered to patients with COPD who had a $\mathrm{VO}_{\text {2peak }} \leq 15.0 \mathrm{~mL} /$ $\mathrm{kg}$ per min or an $\mathrm{FEV}_{1} \leq 50 \%$ of the predicted value and were awaiting surgical resection. The inclusion of patients in the PRP was not a reason for postponing surgical resection in any case. Patients who were deemed fit for surgery underwent open thoracotomy or video-assisted lobectomy three weeks after the beginning of PRP. COPD treatment was not modified during the observation period. Complete functional assessment, including spirometry, DLCO measurement, and CPET, was carried out, in accordance with our routine practice, before and after the PRP, both prior to surgery.

\section{CPET and evaluation of dyspnea}

Before and after the PRP, CPET was performed using a ramp protocol and breath-by-breath measurements on a cycle ergometer (Ergoline Ergoselect; SensorMedics, Milan, Italy) connected to computerized analyzer (Vmax encore 29C; SensorMedics). Hemodynamic and respiratory parameters were monitored during the test, including blood pressure, $\mathrm{SpO}_{2}$, heart rate $(\mathrm{HR})$, electrocardiogram, exhaled $\mathrm{O}_{2}$, and exhaled $\mathrm{CO}_{2}$. The test started with a 2-min evaluation of the patient at rest, followed by a 2-min warm-up period during which the patient cycled freely. Exercise intensity was gradually increased based on the predicted workload for each patient. The test was interrupted when the patient reached the maximum predicted HR or whether other limitations occurred. At the end of the CPET, the reasons for exercise limitation and the perception of dyspnea, determined by the Borg scale, were registered.

\section{PRP}

A PRP, in daily 3-h sessions from Monday to Friday, was carried out for 3 consecutive weeks. ${ }^{(10)}$ In brief, the program consisted of respiratory exercises on a bench, on a mattress pad, and using wall bars. Subsequently, high-intensity training for the upper limbs (on a rowing ergometer) and the lower limbs (on a treadmill or cycle ergometer) were carried out. For rowing and walking, training was conducted at a perceived exertion rating of 15-17 (hard to very hard) on the Borg Rating of Perceived Exertion scale. ${ }^{(13)}$ For cycling, the exercise workload was set according to CPET results for each patient, starting with $70 \%$ of the maximum score reached in CPET and increased by 10 $W$ when the patient was able to tolerate that workload for 30 min. ${ }^{(10,11)}$ High-intensity exercises lasted for 10-15 min. In the presence of physical exhaustion or severe dyspnea, the exercise was prematurely interrupted. The training sessions were supervised by an experienced physical therapist.

\section{Statistical analysis}

Data are reported as frequencies, means, and standard deviations; for respiratory parameters, absolute and percentage of the predicted values were considered. Intragroup analysis was performed using a t-test for dependent variables. The level of significance was set at $5 \%$.

\section{RESULTS}

Of the 32 patients evaluated, 7 were excluded because of incomplete PRP or lack of post-PRP assessment: 5 patients (15.6\%) underwent surgery at other hospitals; and $2(6.2 \%)$ abandoned the PRP after less than one week. Therefore, the sample comprised 25 patients (17 males and 8 females) diagnosed with resectable NSCLC (stage I-IIIa). The mean age was 62.3 \pm 6.0 years. The baseline characteristics of the patients are summarized in Table 1, whereas Table 2 shows the comparison of characteristics between included and excluded patients. All of the patients had a baseline $\mathrm{VO}_{\text {2peak }}$ ranging from 10 to $20 \mathrm{~mL} / \mathrm{kg}$ per min (mean, $14.7 \pm 2.5 \mathrm{~mL} / \mathrm{kg}$ per $\mathrm{min})$. Three patients (12\%) had a previous diagnosis of chronic heart failure, and 16 (64\%) had systemic hypertension. Table 3 compares spirometry and CPET parameters before and after the 3-week PRP. As expected, the major spirometry variables showed no significant differences between the pre- and post-PRP values. Conversely, the $\mathrm{VO}_{2 \text { peak }}$ improved significantly after the PRP $(14.7 \pm 2.5 \mathrm{~mL} / \mathrm{kg}$ per min vs. $18.2 \pm 2.7 \mathrm{~mL} / \mathrm{kg}$ per min; $\mathrm{p}<0.001)$, as did the $\mathrm{V}_{\mathrm{E}} / \mathrm{VCO}_{2}$ slope $(32.0 \pm 2.8$ vs. $30.1 \pm 4.0 ; \mathrm{p}<0.01)$.

\section{DISCUSSION}

In the present study, we found that a high-intensity PRP in patients with COPD undergoing lung resection for NSCLC might influence exertional parameters by increasing $\mathrm{VO}_{\text {2peak }}$ and reducing the $\mathrm{V}_{\mathrm{E}} / \mathrm{VCO}_{2}$ slope. The risk of lung cancer is approximately five times greater in patients with COPD than in smokers without COPD, regardless of age and smoking history. (14-18) In patients in the early stages of NSCLC, ${ }^{(19)}$ the 
Table 1. Baseline characteristics of the patients $(N=25)$.

\begin{tabular}{|c|c|}
\hline Characteristic & Result \\
\hline Age, years & $62.3 \pm 6.0$ \\
\hline Gender, male & $17(68)$ \\
\hline Smoking history, pack-years & $37.2 \pm 8.0$ \\
\hline $\mathrm{BMI}, \mathrm{kg} / \mathrm{m}^{2}$ & $26.1 \pm 3.4$ \\
\hline $\mathrm{FEV}_{1}, \mathrm{~L}$ & $1.67 \pm 0.7$ \\
\hline $\mathrm{FEV}_{1}, \%$ predicted & $61.5 \pm 22.0$ \\
\hline $\mathrm{FEV}_{1} / \mathrm{FVC}$ & $54.1 \pm 13.1$ \\
\hline TLC, \% predicted & $108.7 \pm 28.6$ \\
\hline IC, \% predicted & $84.4 \pm 14.3$ \\
\hline IC/TLC & $38.5 \pm 12.1$ \\
\hline RV, \% predicted & $130.0 \pm 39.4$ \\
\hline DLCO, \% predicted & $67.2 \pm 18.1$ \\
\hline $\mathrm{VO}_{2 \text { peak }}, \mathrm{mL} / \mathrm{kg}$ per min & $14.7 \pm 2.5$ \\
\hline \multicolumn{2}{|l|}{ COPD staging } \\
\hline 1 & $4(16)$ \\
\hline II & $9(36)$ \\
\hline III/IV & $12(48)$ \\
\hline \multicolumn{2}{|l|}{ COPD treatment } \\
\hline LAMA & $3(12)$ \\
\hline LABA & $1(4)$ \\
\hline LABA/LAMA & $16(64)$ \\
\hline LABA/LAMA/ICS & $5(20)$ \\
\hline \multicolumn{2}{|l|}{ TNM staging } \\
\hline la & $6(24)$ \\
\hline $\mathrm{lb}$ & $8(32)$ \\
\hline Ila & $7(28)$ \\
\hline IIb & $4(16)$ \\
\hline
\end{tabular}

BMI: body mass index; IC: inspiratory capacity; $\mathrm{VO}_{2 \text { peak }}$ : peak oxygen uptake; LABA: long-acting $\beta_{2}$ agonists; LAMA: long-acting muscarinic antagonists, ICS: inhaled corticosteroids; and TNM: tumor-lymph nodemetastasis. aValues expressed as $\mathrm{n}(\%)$ or mean \pm SD.

presence of coexisting COPD has been correlated with shorter survival, although no convincing evidence of such a correlation has been found in patients with nonresectable tumors. ${ }^{(20)}$ In our study population, most of the subjects were heavy smokers with poor pulmonary function test results, which did not improve significantly after the high-intensity PRP. These data are consistent with those of similar studies in the literature $(21,22)$ and could have been due to the short duration of the PRP. Nevertheless, exertional parameters improved meaningfully, indicating the positive effects of such a program on overall fitness and efficiency of $\mathrm{CO}_{2}$ elimination. A previous prospective study $^{(10)}$ showed that $\mathrm{VO}_{2 \text { peak }}$ could be influenced by a PRP. To our knowledge, there are as yet no data about the $\mathrm{V}_{\mathrm{E}} / \mathrm{VCO}_{2}$ slope in relation to a PRP. The $\mathrm{V}_{\mathrm{E}} / \mathrm{VCO}_{2}$ slope reflects a combination of factors that underlie ventilatory inefficiency and can be altered by both pulmonary and cardiac diseases. However, Corrà et al. ${ }^{(23)}$ reported that $a \mathrm{~V}_{\mathrm{E}} / \mathrm{VCO}_{2}>35$ is a predictor of mortality, independently from $\mathrm{VO}_{2 \max }$ in a cohort of patients with chronic heart failure. Those results were subsequently corroborated in three large studies that involved patients undergoing lung resection for NSCLC. ${ }^{(3,5,8)}$ A comprehensive retrospective analysis investigated 145 consecutive patients with COPD referred for preoperative evaluation. ${ }^{(8)}$ The authors concluded that a high $\mathrm{V}_{\mathrm{E}} / \mathrm{VCO}_{2}$ slope can be considered an independent predictor of postoperative mortality among patients with COPD undergoing lung resection, no deaths having occurred in patients with a $\mathrm{V}_{\mathrm{E}} / \mathrm{VCO}_{2}$ slope within the normal range. ${ }^{\left({ }^{8}\right)}$ Brunelli et al. ${ }^{(3)}$ found that the $\mathrm{V}_{\mathrm{E}} / \mathrm{VCO}_{2}$ slope was the only significant factor associated with the risk of complications, showing that the incidence of complications and mortality were 3- and 12-fold higher, respectively, among patients with a $\mathrm{V}_{\mathrm{E}} / \mathrm{VCO}_{2}$ slope $>35$ than among those with lower values. More recently, a $\mathrm{V}_{\mathrm{E}} / \mathrm{VCO}_{2}$ slope $>$ 35 (at maximal exercise) was strongly associated with the probability of mortality and postoperative complications, as well as with a 1-year survival rate of $40 \%$. ${ }^{(5)}$ However, the latter study had one major weakness: the authors did not clearly state whether mortality was related to cancer or not. The clinical meaning of those findings remains to be determined, not only in the context of postoperative pulmonary complications/mortality after lung resection due to lung cancer but also in the context of the clinical implications of excessive ventilation during exercise on exertional dyspnea in COPD. In fact, a decrease in the $\mathrm{V}_{\mathrm{E}} / \mathrm{VCO}_{2}$ slope after a PRP could be influenced by increased $\mathrm{CO}_{2}$ elimination and by reduced exercise ventilation after training. ${ }^{(24)}$ Porszasz et al. ${ }^{(25)}$ investigated the magnitude of improvement in exercise tolerance and dynamic hyperinflation in a population of severe COPD patients undergoing a 7-week high-intensity PRP. After the PRP, the patients showed decreased dynamic hyperinflation and breathing frequency during a constant work rate test on a cycle ergometer. In addition, the multivariate analysis revealed that the improvement in inspiratory capacity was significantly associated with the changes in exercise tolerance. However, the role of PRPs in the setting of NSCLC surgery has yet to be clarified. Mainini et al., (26) in an elegant systematic review, emphasized that PRPs should be better studied due to the scarcity of randomized clinical trials regarding preoperative and postoperative PRPs, the few such studies having produced inconsistent results. The effects of pulmonary rehabilitation in COPD patients undergoing NSCLC surgery are currently under investigation in two clinical trials (NCT00363428 and NCT02887521). The effects of a longer PRP, including preoperative and postoperative training, are also under investigation (NCT02405273).

Despite the small number of patients, our study offers novel insights in this field of research. However, the present study has some limitations. First, because of the retrospective design of the study, we were unable to report the 1-year survival rate of the patients studied, which would be an interesting long-term outcome measure of the value of a PRP. In addition, the number of patients who were unable to complete 
Effects of a high-intensity pulmonary rehabilitation program on the minute ventilation/carbon dioxide output slope

Table 2. Spirometry and cardiopulmonary exercise test parameters before and after the three-week pulmonary rehabilitation program.

\begin{tabular}{lccc|}
\multicolumn{1}{c}{ Parameter } & Before & After & p \\
$\mathrm{FEV}_{1}, \%$ predicted & $61.5 \pm 22.0$ & $61,9 \pm 21.1$ & $\mathrm{~ns}$ \\
$\mathrm{VC}, \%$ predicted & $81.1 \pm 19.0$ & $82.0 \pm 17.8$ & $\mathrm{~ns}$ \\
$\mathrm{FEV}_{1} / \mathrm{VC}$ & $54.1 \pm 13.1$ & $54.5 \pm 14.1$ & $\mathrm{~ns}$ \\
$\mathrm{DLCO}, \%$ predicted & $67.2 \pm 18.1$ & $67.5 \pm 13.2$ & $\mathrm{~ns}$ \\
$\mathrm{VO}_{2 \text { peak }}, \mathrm{mL} / \mathrm{kg}$ per $\min$ & $14.7 \pm 2.5$ & $18.2 \pm 2.7$ & $<0,001$ \\
$\mathrm{VO}_{2 \text { peak }}, \%$ predicted & $64.0 \pm 19.2$ & $81.1 \pm 18.0$ & $<0,001$ \\
$\mathrm{~V}_{\mathrm{E}} / \mathrm{VCO}$ slope & $32.0 \pm 2.8$ & $30.1 \pm 4.0$ & $<0,01$ \\
Peak $\mathrm{HR}, \%$ predicted & $92.1 \pm 1.8$ & $92.3 \pm 2.0$ & $\mathrm{~ns}$ \\
Peak RER & $1.2 \pm 0.3$ & $1.3 \pm 0.2$ & $\mathrm{~ns}$ \\
Breathing reserve, \% & $24.3 \pm 6.1$ & $24.7 \pm 6.4$ & $\mathrm{~ns}$ \\
\hline
\end{tabular}

ns: not significant; $\mathrm{VO}_{2 \text { eak }}$ : peak oxygen uptake; $\mathrm{V}_{\mathrm{E}}$ : minute ventilation; $\mathrm{VCO}_{2}$ : carbon dioxide output; and RER: respiratory exchange ratio.

Table 3. Baseline characteristics of included and excluded patients. ${ }^{a}$

\begin{tabular}{|c|c|c|c|}
\hline Characteristic & Included patients & Excluded patients & p \\
\hline Age, years & $62.3 \pm 6.0$ & $60.4 \pm 5.1$ & 0.45 \\
\hline \multicolumn{4}{|l|}{ Gender } \\
\hline Male & $17(68.0)$ & $5(71.4)$ & 0.94 \\
\hline Female & $8(32.0)$ & $2(28.6)$ & 0.90 \\
\hline Smoking history, pack-years & $37.2 \pm 8.0$ & $32.2 \pm 9.1$ & 0.16 \\
\hline $\mathrm{BMI}, \mathrm{kg} / \mathrm{m}^{2}$ & $26.1 \pm 3.4$ & $27.5 \pm 2.9$ & 0.33 \\
\hline $\mathrm{FEV}_{1}, \mathrm{~L}$ & $1.67 \pm 0.70$ & $1.84 \pm 0.60$ & 0.56 \\
\hline $\mathrm{FEV}_{1}, \%$ predicted & $61.5 \pm 22.0$ & $63.4 \pm 26.2$ & 0.84 \\
\hline $\mathrm{FEV}_{1} / \mathrm{FVC}$ & $54.1 \pm 13.1$ & $59.1 \pm 10.1$ & 0.36 \\
\hline TLC, \% predicted & $108.7 \pm 28.6$ & $111.1 \pm 27.2$ & 0.83 \\
\hline IC, \% predicted & $84.4 \pm 14.3$ & $87.1 \pm 12.9$ & 0.64 \\
\hline IC/TLC & $38.5 \pm 12.1$ & $35.4 \pm 15.9$ & 0.64 \\
\hline RV, \% predicted & $130.0 \pm 39.4$ & $124.5 \pm 42.1$ & 0.76 \\
\hline DLCO, \% predicted & $67.2 \pm 18.1$ & $71.0 \pm 16.5$ & 0.60 \\
\hline $\mathrm{VO}_{2 \text { peak }}, \mathrm{mL} / \mathrm{kg}$ per min & $14.7 \pm 2.5$ & $15.1 \pm 2.8$ & 0.73 \\
\hline $\begin{array}{l}\mathrm{VO}_{2 \text { peak }}, \% \text { predicted } \\
\mathrm{COPD} \text { staging }\end{array}$ & $64.1 \pm 19.2$ & $67.8 \pm 21.1$ & 0.68 \\
\hline $\mathrm{I} / \mathrm{II}$ & $13(52.0)$ & $3(42.8)$ & 0.80 \\
\hline III/IV & $12(48.0)$ & $4(57.2)$ & 0.81 \\
\hline \multicolumn{4}{|l|}{ TNM staging } \\
\hline$l a-b$ & $14(56.0)$ & $4(57.1)$ & 0.98 \\
\hline Ila-b & $11(44.0)$ & 3 (42.9) & 0.97 \\
\hline
\end{tabular}

BMI: body mass index; IC: inspiratory capacity; $\mathrm{VO}_{2 \text { peak }}$ : peak oxygen uptake; and TNM: tumor-lymph nodemetastasis. ${ }^{a}$ Values expressed as $\mathrm{n}(\%)$ or mean $\pm \mathrm{SD}$.

the PRP and were therefore excluded from the final analysis represents a potential limitation of the study. However, no differences were found between the two groups at baseline.
In conclusion, our results underscore the influence of a high-intensity PRP on ventilation efficiency. Further comprehensive prospective studies are required in order to corroborate these preliminary results.

\section{REFERENCES}

1. Brunelli A, Charloux A, Bolliger CT, Rocco G, Sculier JP, Varela G et al. ERS/ESTS clinical guidelines on fitness for radical therapy in lung cancer patients (surgery and chemo-radiotherapy). Eur Respir J. 2009;34(1):17-41. https://doi.org/10.1183/09031936.00184308

2. Jones LW, Eves ND, Haykowsky $M$, Joy $A A$, Douglas PS Cardiorespiratory exercise testing in clinical oncology research: systematic review and practice recommendations. Lancet Oncol. 2008;9(8):757-65. https://doi.org/10.1016/S1470-2045(08)70195-5
3. Brunelli A, Belardinelli $R$, Pompili $C$, Xiumé $F$, Refai $M$, Salati $M$, Sabbatini A. Minute ventilation-to-carbon dioxide output (VENCO2) slope is the strongest predictor of respiratory complications and death after pulmonary resection. Ann Thorac Surg. 2012;93(6):1802 6. https://doi.org/10.1016//.athoracsur.2012.03.022

4. Kasikcioglu E, Toker A, Tanju S, Arzuman P, Kayserilioglu A, Dilege $S$, et al. Oxygen uptake kinetics during cardiopulmonary exercise testing and postoperative complications in patients with lung 
cancer. Lung Cancer. 2009;66(1):85-8. https://doi.org/10.1016/j. lungcan.2008.12.024

5. Shafiek H, Valera JL, Togores B, Torrecilla JA, Sauleda J, Cosío BG. Risk of postoperative complications in chronic obstructive lung diseases patients considered fit for lung cancer surgery: beyond oxygen consumption. Eur J Cardiothoracic Surg. 2016;50(4):772-779. https://doi.org/10.1093/ejcts/ezw104

6. Campione A, Terzi A, Bobbio M, Rosso GL, Scardovi AB, Feola M. Oxygen pulse as a predictor of cardiopulmonary events in lung resection. Asian Cardiovasc Thorac Ann. 2010;18(2):147-52. https:// doi.org/10.1177/0218492310361792

7. Wang JS, Abboud RT, Evans KG, Finley RJ, Graham BL. Role of CO diffusing capacity during exercise in the preoperative evaluation for lung resection. Am J Respir Crit Care Med. 2000;162(4 Pt 1):1435-44. https://doi.org/10.1164/airccm.162.4.2001117

8. Torchio R, Guglielmo M, Giardino R, Ardissone F, Ciacco C, Gulotta $C$, et al. Exercise ventilatory inefficiency and mortality in patients with chronic obstructive pulmonary disease undergoing surgery for non-small-cell lung cancer. Eur J Cardiothorac Surg. 2010;38(1):14-9. https://doi.org/10.1016/j.ejcts.2010.01.032

9. Brunelli A. Ventilatory efficiency slope: an additional prognosticator after lung cancer surgery. Eur J Cardiothoracic Surg. 2016;50(4):780781. https://doi.org/10.1093/ejcts/ezw127

10. Stefanelli F, Meoli I, Cobuccio R, Curcio C, Amore D, Casazza D, et al. High-intensity training and cardiopulmonary exercise testing in patients with chronic obstructive pulmonary disease and non-smallcell lung cancer undergoing lobectomy. Eur J Cardiothorac Surg. 2013;44(4):e260-5. https://doi.org/10.1093/ejcts/ezt375

11. Licker M, Karenovics W, Diaper J, Frésard I, Triponez F, Ellenberger $C$, et al. Short-Term Preoperative High-Intensity Interval Training in Patients Awaiting Lung Cancer Surgery: A Randomized Controlled Trial. J Thorac Oncol. 2017;12(2):323-333. https://doi.org/10.1016/i. jtho.2016.09.125

12. Salvi R, Meoli I, Cennamo A, Perrotta F, Saverio Cerqua F. Montesano R, et al. Preoperative high-intensity training in frail old patients undergoing pulmonary resection for NSCLC. Open Med (Wars). 2016;11(1):443-448. https://doi.org/10.1515/med-2016-0079

13. Hwang $C L$, Yu CJ, Shih JY, Yang PC, Wu YT. Effects of exercise training on exercise capacity in patients with non-small cell lung cancer receiving targeted therapy. Support Care Cancer. 2012;20(12):3169-77. https://doi.org/10.1007/s00520-012-1452-5

14. Young RP, Hopkins RJ, Christmas T, Black PN, Metcalf P, Gamble GD. COPD prevalence is increased in lung cancer, independent of age, sex and smoking history. Eur Respir J. 2009:34(2):380-6. https:// doi.org/10.1183/09031936.00144208

15. Mayne ST, Buenconsejo J, Janerich DT. Previous lung disease and risk of lung cancer among men and women nonsmokers. Am J Epidemiol. 1999;149(1):13-20. https://doi.org/10.1093/oxfordjournals. aje.a009722

16. Turner MC, Chen Y, KrewskiD Calle EE, Thun MJ Chronic obstructive pulmonary disease is associated with lung cancer mortality in a prospective study of never smokers. Am J Respir Crit Care Med. 2007;176(3):285-90. https://doi.org/10.1164/rccm.200612-17920C

17. Adcock IM, Caramori G, Barnes PJ. Chronic obstructive pulmonary disease and lung cancer: new molecular insights. Respiration. 2011;81(4):265-84. https://doi.org/10.1159/000324601

18. Perrotta F, Mazzeo F, Cerqua FS. Which treatment for obstructive airway disease: The inhaled bronchodilators. Pulm Pharmacol Ther. 2017;43:57-59. https://doi.org/10.1016/j.pupt.2017.01.003

19. Lee SJ, Lee J, Park YS, Lee CH, Lee SM, Yim JJ, et al. Impact of chronic obstructive pulmonary disease on the mortality of patients with non-small-cell lung cancer. J Thorac Oncol. 2014;9(6):812-7. https://doi.org/10.1097/JTO.0000000000000158

20. Mina N, Soubani AO, Cote ML, Suwan T, Wenzlaff AS, Jhajhria S, et al. The relationship between chronic obstructive pulmonary disease and lung cancer in African American patients. Clin Lung Cancer. 2012;13(2):149-56. https://doi.org/10.1016/j.cllc.2011.09.006

21. Bobbio A, Chetta A, Ampollini L, Primomo GL, Internullo E, Carbognani $P$, et al. Preoperative pulmonary rehabilitation in patients undergoing lung resection for non-small cell lung cancer. Eur J Cardiothoracic Surg. 2008;33(1):95-8. https://doi.org/10.1016/i.ejcts.2007.10.003

22. Ramponi S, Tzani P, Aiello M, Marangio E, Clini E, Chetta A. Pulmonary rehabilitation improves cardiovascular response to exercise in COPD. Respiration. 2013;86(1):17-24. https://doi.org/10.1159/000348726

23. Corrà U, Mezzani A, Bosimini E, Giannuzzi P. Cardiopulmonary exercise testing and prognosis in chronic heart failure: a prognosticating algorithm for the individual patient. Chest. 2004;126(3):942-50. https://doi.org/10.1378/chest.126.3.942

24. Neder JA, Berton DC, Arbex FF, Alencar MC, Rocha A, Sperandio $\mathrm{PA}$, et al. Physiological and clinical relevance of exercise ventilatory efficiency in COPD. Eur Respir J. 2017;49(3). pii: 1602036. https:// doi.org/10.1183/13993003.02036-2016

25. Porszasz J, Emtner M, Goto S, Somfay A, Whipp BJ, Casaburi R. Exercise training decreases ventilatory requirements and exerciseinduced hyperinflation at submaximal intensities in patients with COPD. Chest. 2005;128(4):2025-34. https://doi.org/10.1378/ chest.128.4.2025

26. Mainini C, Rebelo PF, Bardelli R, Kopliku B, Tenconi S, Costi S, et al. Perioperative physical exercise interventions for patients undergoing lung cancer surgery: What is the evidence? SAGE Open Med. 2016;4:2050312116673855. https://doi. org/10.1177/2050312116673855 